Античная древность и средние века. 2019. Т. 47. С. 89-109

УДК УДК 94(495)+ 94(479.22)+929.7.034

DOI 10.15826/adsv.2019.47.007

\title{
Э.А. Хайрединова
}

Институт археологии Крыма РАН, г. Симферополь, Россия

\section{ПЕРСТНИ С ИЗОБРАЖЕНИЕМ КРЕСТА ВТОРОЙ ПОЛОВИНЫ VI-VII В. ИЗ ЮГО-ЗАПАДНОГО КРЫМА}

Аннотация: Во второй половине VI-VII в. в Юго-Западном Крыму у готоаланского населения пользовались популярностью привозившиеся из Византии и производившиеся в местных мастерских по импортным образцам перстни с изображением креста. По особенностям изображения они представлены четырьмя вариантами: $A$-с глубоко прорезанным равноконечным крестом с расширяющимися концам; $D-$ с крестом, образованным гравированными геометрическими фигурами; $B-c$ крестом из тонких врезных линий с поперечными черточками на концах; $\Gamma$-с щитком в форме креста с расширяющимися концами, поверхность которого инкрустирована стеклом. Происходящие из Крыма перстни с крестом принадлежали мужчинам-воинам и молодым женщинам, имевшим высокий социальный статус. Большинство перстней происходит из женских захоронений. Женщины носили их на руках, как правило, на правом указательном пальце и в нагрудных ожерельях, соединявших фибулы. Изображение креста не использовалось для декорирования предметов. Крест прежде всего религиозный символ, знак принадлежности христианской конфессии. Видимо, и перстни с изображением креста не были простым украшением, а в представлении носивших их людей приравнивались к предмету личного благочестия, служили своего рода аналогом нательному кресту. Кроме того, в самой символике креста заложена защитно-охранительная функция. Изображение креста на щитке перстня наделяло украшение свойствами амулета, оберегавшего носившего его человека от всяких бед. Изучение перстней позволяет не только расширить знания об украшениях, бытовавших в раннесредневековое время, но и пополняет наши сведения о повседневной жизни и верованиях жителей раннесредневекового Крыма. Находки подобного рода свидетельствуют о единстве культуры в христианском мире и являются наглядным примером тесных экономических и культурных связях Крыма с Византийской империей в эпоху раннего Средневековья.

Ключевые слова: Византия, Юго-Западный Крым, крымские готы, византийские украшения, перстни, крест

Поступила в редакиию 22.06.2019

Принята к печати 11.11.2019 


\section{Э.А. Хайрединова}

Среди предметов византийского круга, распространившихся в раннесредневековое время в Юго-Западном Крыму у гото-аланского населения под влиянием христианства, выделяется группа перстней с изображением креста (рис. 1). Они найдены в могильниках Лучистое, Скалистое, Эски-Кермен и Алония. По форме и способу изображения креста перстни представлены четырьмя вариантами: $A$-с глубоко прорезанным равноконечным крестом с расширяющимися концам (рис. 2, 4); 5 -с крестом, образованным гравированными геометрическими фигурами (рис. $3,1,8$, $16 ; 4,5) ; B$-с крестом из тонких врезных линий с поперечными черточками на концах (рис. 5,2 ); $\Gamma$-с щитком в форме креста с расширяющимися концами, поверхность которого инкрустирована стеклом (рис. 6, 6).

Перстни вариантов $A$ и $Б$ одинаковы по форме и сделаны из серебра в единой технике: к кольцу из круглой в сечении проволоки с сомкнутыми концами припаян круглый пластинчатый щиток. Такая форма и способ изготовления характерны для византийских перстней, бытовавших в VI-VII вв. как на территории империи, так и в областях, имевших политические и экономические связи с ней. Перстни с круглым пластинчатым щитком найдены в Италии, Восточном Средиземноморье и Малой Азии (рис. 3, 11) ${ }^{1}$. Они встречаются в Подунавьев погребениях авар (рис. $3,12,14,15)^{2}$ и известны в степях Северного Причерноморья - в поминальных комплексах и захоронениях хазарской воинской элиты ${ }^{3}$. Перстни этого типа делали не только из золота и серебра, но еще из бронзы и железа. Помимо христианских символов и сюжетов, на круглых щитках перстней гравировались инвокативные надписи или монограммы имени владельца (рис. 4, 3). В Юго-Западном Крыму у гото-аланского населения перстни с круглым щитком были одним из наиболее популярных женских украшений во второй половине VI-VII вв. (рис. 4, 2, 3, 5; 6, 7) ${ }^{4}$.

На щитке перстня варианта $A$, происходящего из могильника Алония, вырезан глубокий равноконечный крест с расширяющими-

\footnotetext{
${ }^{1}$ CM.: Vikan G. Early Christian and Byzantine Rings in the Zucker Family Collection // The Journal of the Walters Art Gallery. 1987. T. 45. P. 39. Fig. 12; 13; 15. Baldini-Lippolis I. L'oreficeria nell' Imperio di Constantinopoli tra IV e VII secolo. Bari, 1999. P. 189, 199-201. Die Welt von Byzanz. Europas Östliches Erbe / Ed. L. Wamser. München, 2004. S. 329. Kat. No 643-645, 647-650. Залесская В. Н. Памятники византийского прикладного искусства IV-VII вв.: каталог коллекции. СПб., 2006. Кат. № 80, 98, 100, 111, 113, 117.

${ }^{2}$ См.: Garam E. Funde byzantinischer Herkunft in der Awarenzeit vom Ende des 6. bis zum Ende des 7. Jahrhunderts. Budapest, 2001. S. 7480. Abb. 9. Taf. 49, 1-3,6-13.

3 См.: Залесская В.Н. Памятники византийского прикладного искусства... С. 92. Кат. № 114-116. Айбабин А. И. Археологическое наследие хазар времени создания каганата // МАИЭТ. 2013. Вып. ХVIII. С. 291-292.

${ }^{4}$ См.: Айбабин А.И., Хайрединова Э.А. Крымские готы страны Дори (середина IIIVII вв.). Симферополь, 2017. С. 260. Рис. 176, 6,7; 182, 6; 187, 4; 194, 4.
} 
Перстни с изображением креста второй половины VI-VII в.

ся концами (рис. 2, 4). Диаметр кольца 2,4 см, размеры щитка: диаметр-1,2 см, толщина 0,2 см. Перстень обнаружен в склепе 2, в женском погребении 2 вместе с парой двупластинчатых фибул (рис. $2,1,2$ ) и орлиноголовой пряжкой первого варианта (рис. 2, 3), что позволяет отнести время захоронения ко второй половине VI в ${ }^{5}$. В подтверждении этой даты укажем на то, что в склепе 2 рядом с названным женским погребением зачищен мужской костяк с воинским поясным геральдическим набором, подобным поясным гарнитурам второй половины VI в. из Садовско-Кале, Суук-Су и Лучистого ${ }^{6}$. В качестве аналогий для публикуемого перстня из Алонии можно указать византийские золотые перстни с выгравированным крестом из собрания Музея украшений в Пфорцхайме (Schmuckmuseum Pforzheim) (рис. 2, 5) и из коллекции Музея Канеллопулоса в Афинах (Kanellopoulos Museum) ${ }^{7}$. Оба перстня лишены археологического контекста, по форме и декору исследователи датируют их VI-VII вв.

В могильниках Эски-Кермен, Скалистое и Лучистое найдены перстни варианта $\bar{C}$ с крестом из выгравированных геометрических фигур. На щитке перстня из Лучистого крест образован четырьмя ромбами (рис. 3, 16а), а на перстнях из Эски-Кермена и Скалистого-кругами и треугольниками (рис. 3, 1, 8a). Щиток перстня из Скалистого декорирован по контуру точками (рис. 3,1$)$. Размеры перстней: диаметр кольца 2,2-2,3 см; диаметр щитка 1,1 см, толщина-0,2 см.

В Лучистом перстень выявлен в склепе 228 , в погребении молодой женщины с орлиноголовой пряжкой пятого варианта второй половины VII в. (рис. 4,6$)^{8}$. Подобные по форме перстни с крестом из гравированных ромбов известны в погребениях авар (рис. $3,13,15)$. Один из них, серебряный (рис. 3, 15), относится к византийской продукции VII в. Второй перстень, происходящий из могилы начала VIII в., от-

\footnotetext{
${ }^{5}$ См.: Айбабин А.И. Хронология могильников Крыма позднеримского и раннесредневекового времени // МАИЭТ. 1990. Вып. І. С. 33. Рис. 2, 81. Айбабин А.И., Хайрединова Э. А. Могильник у села Лучистое. Т. I (Раскопки 1977, 1982-1984 гг.). Симферополь; Керчь, 2008. Рис. 12, I.

${ }^{6}$ См.: Uense S. Die spätantiken Befestigungen von Sadovec (Bulgarien). München, 1992. S. 188. Abb. 15, 1-4. Айбабин А. И., Хайрединова Э. А. Могильник у села Лучистое. Т. II (Раскопки 1984, 1986, 1991, 1993-1995 годов). Симферополь; Керчь, 2014. С. 34. Рис. 9, 10-13. Хайре динова Э. А. Геральдический поясной набор с христианской символикой второй половины VI в. из могильника у с. Лучистое // МАИЭТ. 2018. Вып. ХХІІІ. С. 33. Рис. 6.

${ }^{7}$ Cм.: Age of Spirituality: Late Antique and Early Christian Art, Third to Seventh Century : Catalogue of the Exhibition at the Metropolitan Museum of Art / Ed. K. Weitzmann. New York, 1979. P. 328-329. Cat. No 308; Spieser J.-M. Collection Paul Canellopoulos (II). Bagues romaines et médiévales // Bulletin de correspondence hellénique. 1972. T. 96, 1. P. 130-131. Cat. No 16. Fig. 30.

8 См.: Айбабин А.И. Хронология могильников Крыма... С. 33-34. Рис. 2, 166. Айбабин А. И., Хайрединова Э. А. Могильник у села Лучистое. Т. І... Рис. 12.1, V.
} 


\section{Э.А. Хайрединова}

лит из бронзы и является местной имитацией византийских изделий (рис. 3, 13) ${ }^{9}$.

В Скалистом, в склепе 325 перстень с крестом из треугольников лежал в мужском погребении вместе с деталями геральдического поясного набора и цельнолитой пряжкой с овальной рамкой и прямоугольным щитком второй половины VII в. (рис. 3, 2-4) ${ }^{10}$. В могильнике на склоне плато Эски-Кермен перстень варианта Б обнаружен в склепе 193, ограбленном в древности. Среди перемещенных грабителями костяков собраны византийские цельнолитые пряжки с овальным и крестовидным щитком вариантов II4-3 и II7-4 (рис. 3, 6, 7), бытовавшие в Юго-Западном Крыму во второй половине VII-первой половине VIII вв ${ }^{11}$. Перстень, подобный найденным в Скалистом и Эски-Кермене, выявлен в Пергаме, на северо-западе Малой Азии в погребении воина (рис. 3, 11 ), датированном исследователями ранним VII в ${ }^{12}$. Отметим, что в состав инвентаря названного захоронения входила византийская цельнолитая бронзовая пряжка варианта II-8 с продолговатым фигурным щитком, украшенным перекрещивающимися линиями (рис. 3, 10), время бытования которой относится к более широкому периоду. Так, на Крите, в Элеутерне, такая пряжка найдена в жилище, относящемся к периоду середины VII-начала VIII в. с монетами Константа II (фоллисы выпуска $651 / 54$ и 652/55 гг.) ${ }^{13}$, в Коринфе-в одной из могил у базилики Кранейон с монетами Константа II (641-668) ${ }^{14}$. В Юго-Западном Крыму пряжки варианта II-8 выявлены в Лучистом, в склепе 186-в слое с солидом Константа II (выпуск 647--648 гг.) и орлиноголовой пряжкой пятого варианта второй половины VII в., а в склепах 10 и $105-$ в слоях конца VII-первой половины VIII вв ${ }^{15}$. На склоне Эски-Кермена однотипная пряжка зачищена в склепе 257 второй половины VII в., где так-

\footnotetext{
${ }^{9}$ Cм.: Garam E. Funde byzantinischer Herkunft... S. 78-80, Taf. 49, 11,12.

${ }^{10}$ См.: Айбабин А.И. Этническая история ранневизантийского Крыма. Симферополь, 1999. С. 317. Табл. XXX, 46.

${ }^{11}$ См.: Там же. Табл. XXX, 42,45; XXXII, 11.

${ }^{12}$ Cм.: Otten T., Evans J., Lamb A., Müldner G., Pirson A., Teegen W.-R. Ein frühbyzantinisches Waffengrab aus Pergamon. Interpretationsmöglichkeiten aus archäologischer und naturwissenschaftlicher Sicht // Istanbuler Mitteilungen. 2011. T. 61. S. 357, 406. Abb. 10-12. Pirson A. Byzantinischer Schmuck und Trachtbestanteile aus Pergamon // Byzas. 2012. T. 15. S. 179-181. Abb. 9-10.

${ }^{13}$ См.: Poulou-Papadimitriou N. Les plaques-boucles byzantines de l'île de Crète (fin IVe-IXe siècle) // Mélanges J.-P. Sodini. Travaux et Mémoires. 2005. Vol. 15. P. 697.

${ }^{14}$ Cм.: Pallas D. Données nouvelles sur quelques boucles et fibules considérées comme avares et slaves sur Corinthe entre le VI-e et le IX-e siècles // Byzantinobulgarica. 1981. T. 7. P. 298 299. Fig. 5a.

${ }^{15}$ См.: Айбабин А.И., Хайрединова Э. А. Могильник у села Лучистое. Т. І... С. 33, 42. Рис. $17,1,2 ; 22,1,8,11$.
} 
Перстни с изображением креста второй половины VI-VII в.

же обнаружена монета Константина IV Погонат (668-685) ${ }^{16}$. Учитывая датировку сопутствующих находок, можно говорить о том, что перстни варианта $Б$ бытовали во второй половине VII в.

Крест из гравированных треугольников, обращенных вершиной к центру, встречается не только на перстнях, но и на византийских пряжках и различных деталях поясной гарнитуры раннесредневекового времени (рис. 3,5$)$. Особенно часто такой крест размещался на язычках или на круглом декоративном выступе на завершении щитка шарнирных пряжек второй половины VII--VIII вв., происходящих из Сирии и Малой Азии ${ }^{17}$.

Бронзовые перстни варианта $B$ найдены в могильниках Лучистое и Эски-Кермен. Перстень из могильника у с. Лучистое сделан в виде кольца из круглой в сечении проволоки с сомкнутыми концами, к которым припаян квадратный пластинчатый щиток (рис. 5, 2). Диаметр перстня 2,2 см; размеры щитка $0,9 x 0,9$ см, толщина $-0,2$ см. Он выявлен в склепе 154, в женском погребении с орлиноголовой пряжкой второго варианта, датированной концом VI-первой четвертью VII вв. (рис. 5, $1)^{18}$. Перстни с квадратным щитком известны с позднеримского времени ${ }^{19}$. Особой популярностью они пользовались в Восточном Средиземноморье в VI-VII вв ${ }^{20}$. В Юго-Западном Крыму перстни такой формы, но с гладким, не декорированным щитком встречаются в погребениях второй половины VI-VII вв. (рис. 4, 1) ${ }^{21}$.

На щитке перстня из Лучистого тонкими врезными линиями изображен равноконечный крест с поперечными черточками на концах, совмещенный с христограммой из инициалов имени Христа-'I(пбои̃ $)$ $\mathrm{X}(\rho ı \tau \tau$ ś) (рис. 5, 2a). Этот вариант христограммы, известный с последней трети III в., был менее распространен, чем появившаяся в начале

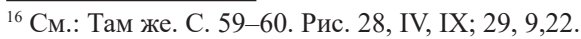

${ }^{17}$ Cм.: Kazanski M. Qal'at Sem'an. Vol. IV: Rapport final. Fascicule 3: Les objets métalliques. Beyrout, 2003. P. 37, 39, 112. Fig. 4, 4,5. Schulze-Dörrlamm M. Byzantinische Gürtelschnallen und Gürtelbeschläge im Römisch-Germanischen Zentralmuzeum. T. II: Die Schnallen mit Scharnierbeschläg und die Schnallen mit angegossenem Riemendurchzug des 7. bis 10 . Jahrhunderts. Mainz, 2009. S. 139-142, 160-195, 358. Typ F2, F7, F8. Kat. No 328, 357, 365 , 370, 380, 385, 387.

${ }^{18}$ См.: Айбабин А. И., Хайрединова Э. А. Могильник у села Лучистое. Т. І... С. 21. Рис. 12, II.

${ }^{19} \mathrm{CM}$.: Art of Late Rome and Byzantium in the Virginia Museum of Fine Arts / Eds. A. Gonosová, Ch. Kondoleon. Richmond, 1994. P. 36-37. Cat. No 3.

${ }^{20}$ CM.: Everyday Life in Byzantium / Ed. D. Papanikola-Bakirtzi. Athens, 2002. P. 438. Cat. No 571. Die Welt von Byzanz... S. 329. Kat. No 640, 641. Залесская В.Н. Памятники византийского прикладного искусства... С. 87. Кат. № 91.

${ }^{21}$ См.: Айбабин А.И., Хайрединова Э.А. Могильник у села Лучистое. Т. II... С. 222. Табл. 74, 3. Ajbabin A. I., Hajredinova E. A. Ein neuer gotischer Fundkomplex aus dem Gräberfeld beim Dorf Lučistoe // Studia Barbarica: Profesorowi A. Kokowskiemu w 65. rocznicę urodzin. T. I. Lublin, 2018. S. 482, 487. Abb. 1, 15; 3, 3. 


\section{Э.А. Хайрединова}

IV в. хризма, монограмма из «Х» и «Р»-двух первых букв имени Христа $^{22}$. Тем не менее, он встречается на раннесредневековых перстнях и пряжках ${ }^{23}$. Объединенное изображение христограммы и креста можно увидеть на стеклянных вставках, украшавших перстни IV в. (рис. 5, 5) ${ }^{24}$, на коптских тканях V-VI вв ${ }^{25}$. и происходящих из Египта браслетах VIVII вв. (рис. 5,4$)^{26}$, а также на распространенных в конце VII-начале IX вв. по всей империи бронзовых шарнирных пряжках типа «Коринф» $(\text { рис. } 5,6)^{27}$. На браслетах и пряжках изображение помещали на круглые плоские детали, по форме и размеру аналогичные щиткам перстней.

На круглом плоском щитке литого перстня варианта $B$, происходящего из могильника на склоне плато Эски-Кермен, прорезан крест с поперечными черточками на концах, из центра которого исходят лучи (рис. 5, 3,3a). Рисунок на щитке можно интерпретировать как стилизованное изображение креста, излучающего лучи света. Подобная композиция встречается на небольших глиняных ампулах VI в. из Сирии и Малой Азии, служивших евлогиями, привозившимися паломниками из святых мест ${ }^{28}$. Датировка названного перстня из Эски-Кермена затруднительна, так как он происходит из разрушенного грабителями погребального сооружения. Отметим, что на могильнике хоронили с последней четверти VI и до конца IX в ${ }^{29}$.

Одиночное изображение равноконечного креста из тонких врезных линий с поперечными черточками на концах, без дополнительных лучей или пересекающихся линий, встречается на византийских перстнях с круглым щитком конца VI-начала VII вв. из Венгрии (рис. 3, 14) и конца VII-первой половины VIII вв. из Юго-Западного Крыма ${ }^{30}$.

${ }^{22}$ Cм.: Sulzberger M. Le symbole de la croix et les monogrammes de Jésus chez les premiers Chrétien // Byzantion. 1925. Vol. 2. P. 393-397. Hörandner W., Carr A. W. Christogram // The Oxford Dictionary of Byzantium / Ed. A. P. Kazhdan. New York; Oxford, 1991. P. 441.

${ }^{23}$ См.: Riemer E. Romanische Grabfunde des 5.-8. Jahrhunderts in Italien (Internationale Archäologie, 57). Rahden / Westf.,2000. Taf. 101, 6. Spier J. Late Antique and Early Christian Gems. Wiesbaden, 2007. P. 183-185. P1. 143. Cat. No R23-33.

${ }^{24}$ CM.: Spier J. Late Antique and Early Christian Gems... P. 32, Cat. No 142. P1. 20, 142.

${ }^{25}$ CM.: Christliches mit Feder und Faden. Christliches in Texten, Textilien und Alltagsgegenständen aus Ägypten / Eds. J. Henner, H. Förster, U. Horak. Wien, 1999. S. 97. Kat. No 90.

${ }^{26}$ См.: Bénazeth D. L'art du métal au début de l'ère chrétienne. Paris, 1992. P. 191. Cat. No E13517.

${ }^{27}$ См.: Веймарн Е. В., Айбабин А. И. Скалистинский могильник... С. 67. Рис. 44, 4.

${ }^{28}$ См.: Залесская В. Н. Памятники византийского прикладного искусства... С. 230, Кат. № 544, 545. Sodini J. $-P$. La terre des semelles: images pieuses ramenées par les pèlerins des Lieux saints (Terre sainte, Martyria d'Orient) // Journal des savants. 2011. T. 1. P. 121-122. Fig. 38; 39.

${ }_{29}$ См.: Хайрединова Э.А. Раскопки некрополя на склоне плато Эски-Кермен в 20062008 гг. // МАИЭТ. 2010. Вып. XVI. С. 140-213.

${ }^{30}$ См.: Garam E. Funde byzantinischer Herkunft ... S. 75, 300. Taf. 49, 7. Айбабин А.И., Хайрединова Э. А. Могильник у села Лучистое. Т. ІІ... С. 18. Рис. 3, 6,8,9. Табл. 53, 12. 
Перстни с изображением креста второй половины VI-VII в.

К варианту Г отнесен бронзовый перстень из могильника у с. Лучистое, щиток которого имеет форму креста с расширяющимися концами и припаян к кольцу из круглой в сечении проволоки (рис. 6,6$)$. Диаметр кольца 2,4 см; размеры щитка 1,8 х 1,9 см, толщина 0,3 см. Крестовидный щиток изготовлен в виде коробочки с вырезанной из пластины основой, по контуру которой напаян узкий пластинчатый бортик, а в центре-цилиндрическое гнездо. Полости между бортиками и внутри гнезда заполнены белой пастой, а на ней укреплены плоские вставки из желтого прозрачного стекла. В такой же технике сделаны нательные кресты, бытовавшие в Юго-западном Крыму во второй половине VI-первой четверти VII вв. Они были более дешевыми местными подражаниями византийских золотых крестов VI-первой половины VII в., инкрустированных альмандинами, разноцветными камнями или стеклом $^{31}$.

Публикуемый перстень варианта $Г$ выявлен в Лучистом в склепе 43, в женском погребении с парой пальчатых фибул днепровского круга и орлиноголовой пряжкой четвертого варианта второй половины VII в. (рис. 6,5$)^{32}$.

Перстни с крестовидным щитком были популярны в ранневизантийское время. В Сардах, в слое с находками этого периода обнаружен бронзовый перстень с гладким пластинчатым щитком, отлитым в виде креста с расширяющимися концами ${ }^{33}$. Золотой перстень, хранящийся в Художественном музее Уолтерса (The Walters Art Gallery), сделан с кольцом из круглой в сечении проволоки и с припаянным к нему плоским гладким щитком, отлитым в форме креста с закругленными конца ${ }^{34}$. Бронзовый перстень с крестовидным щитком со стеклянными вставками, датированный VI-VII вв., хранится в Византийском и христианском музее в Афинах, а золотые перстни с щитком в форме креста, инкрустированного гранатами, известны среди франкских древностей VI в ${ }^{35}$.

В Юго-Западном Крыму перстни с изображением креста найдены in situ в одном мужском и четырех женских захоронениях. В Скали-

31 См.: Хайрединова Э.А. Византийские кресты с инкрустацией из Юго-Западного Крыма // Вестник Волгоградского государственного университета. Серия 4, История. Регионоведение. Международные отношения. 2017. Т. 23, № 5. С. 86-99.

${ }^{32}$ См.: Айбабин А.И., Хайрединова Э.А. Могильник у села Лучистое. Т. І... С. 21-22. Рис. 12.1, IV. Айбабин А. И., Хайрединова Э. А. Могильник у села Лучистое. Т. II... С. 11. Рис. 1, 16-19. Табл. 8, 4; 10, 1; 11, 6,9,10.

${ }^{33}$ Cм.: Waldbaum J. C. Metalwork from Sardis. London; Cambridge, 1983. P. 130. Cat. No 841. P1. 49, 841.

${ }^{34}$ CM.: Vikan G. Early Christian and Byzantine Rings... C. 37. Fig. 16.

${ }^{35}$ Cм.: Arrhenius B. Garnet Jewelry of the Fifth and Sixth Centuries // From Attila to Charlemagne. Arts of the Early medieval Period in The metropolitan Museum of Art / Eds. K. R. Brown, D. Kidd, Ch. T. Little. New York, 2000. P. 222. Fig. 19.11. 


\section{Э.А. Хайрединова}

стом, в склепе 325 серебряный перстень варианта $Б$ с крестом из выгравированных треугольников зафиксирован в погребении воина, о чем свидетельствуют находки деталей воинского поясного набора (рис. 3, $1-5)^{36}$. Из-за плохой сохранности костяка положение перстня на пальцах рук проследить не удалось. В одновременных мужских погребениях из крымских могильников перстни лежали по одному среди костей пальцев правой руки ${ }^{37}$.

Отметим, что серебряный перстень с крестом из геометрических фигур, аналогичный крымским украшениям варианта $Б$, найден в Пергаме в могиле молодого воина 18-22 лет, похороненного вместе с оружием-тремя дротиками. Судя по расположению перстня на костяке, мужчина-воин носил его на среднем пальце правой руки ${ }^{38}$. В аварском могильнике Budakalász в одном из погребений воина конца VI-начала VII вв. с мечом также найден серебряный византийский перстень с круглым щитком с выгравированным крестом ${ }^{39}$. Видимо в раннесредневековое время в Византии и в регионах, входивших в сферу ее влияния, воины носили по одному серебряному перстню с христианской символикой, скорее всего, на правой руке. Христианская символика часто использовалась в воинском обмундировании варварской элиты, бывшей на службе империи. В качестве примеров можно назвать происходящий из Поэльбья шлем типа Балденхайм начала VI в., в налобной части которого выгравирован крест с расширяющимися концами с буквами альфой и омегой, а также воинские поясные геральдические наборы с изображением креста и виноградной лозы, найденные в Крыму и Подунавье 40 .

Женские погребения с перстнями с изображением креста выявлены в могильниках Лучистое и Алония. Все они принадлежали замужним женщинам, похороненным в соответствующем их статусу парадном костюме, включавшем подпоясанное широким ремнем с большой пряжкой верхнее платье, наплечную накидку, пристегивавшуюся к платью парой одинаковых фибул и специфический набор украшений ${ }^{41}$.

\footnotetext{
${ }^{36}$ См.: Веймарн Е.В., Айбабин А.И. Скалистинский могильник. Киев, 1993. С. 71-72. Рис. $48,15,23,24,31,32$.

${ }^{37}$ См.: Хайрединова Э. А. Перстни и кольца раннесредневекового времени из Керчи // БИ. 2014. Вып. ХХХ. С. 449.

${ }^{38}$ Cм.: Otten T., Evans J., Lamb A., Müldner G., Pirson A., Teegen W.-R. Ein frühbyzantinisches Waffengrab... S. 351-352, 376. Abb. 3; 4.

${ }^{39}$ См.: Garam E. Funde byzantinischer Herkunft... S. 78, 300. Taf. 49, 8.

${ }^{40}$ См.: Droberjar E. A propos des contacts entre l'empire d'Orient et les Germains de l'Elbe au VIe siècle // The Pontic-Danubian Realm in the Period of the Great Migration / Eds. V. Ivanišević, M. Kazanski. Paris; Beograd, 2012. P. 309. Fig. 11. Хайрединова Э. А. Геральдичес кий поясной набор... С. 213-215. Рис. 2-5.

${ }^{41}$ См.: Айбабин А. И., Хайрединова Э. А. Крымские готы... С. 250-299.
} 
Перстни с изображением креста второй половины VI-VII в.

Замужние женщины носили большие пряжки разных форм, однако перстни с изображением креста выявлены только в погребениях с орлиноголовой пряжкой (рис. 2; 4; 5; 6).

В двух женских погребениях из могильников у с. Лучистое и Алония перстни лежали на правой руке, но на фалангах разных пальцев (рис. 4; 6). Женщина, похороненная во второй половине VI в. в склепе 2 могильника Алония, носила перстень с крестом на указательном пальце (рис. 2, II), а погребенная во второй половине VII в. в склепе 43 могильника у с. Лучистое-на среднем пальце (рис. 6, II). У обеих женщин перстни с крестом были не единственными украшениями пальцев рук-на среднем пальце левой руки они носили еще по одному перстню, но без декора (рис. 2, II; 6, II,7).

Особый интерес представляет захоронение молодой женщины, умершей в возрасте 15-20 лет и похороненной во второй половине VII в. в склепе 228 могильника у с. Лучистое (рис. 4). Ее руки были украшены набором из четырех серебряных перстней и одного бронзового кольца (рис. 4, II,15). Судя по зафиксированному на костяке in situ расположению предметов, на правой руке женщина носила три перстня-два на указательном пальце, один на среднем, а на левой руке-кольцо и перстень с изображением креста варианта $\overline{5}$, надетые на указательный и средний пальцы соответственно (рис. 4, S, II, 5). Указательный палец правой руки погребенной украшали два одинаковых по форме серебряных перстня с круглым щитком (рис. 4, D, II, 2, 3). На одном из них выгравирована расположенная кресто-

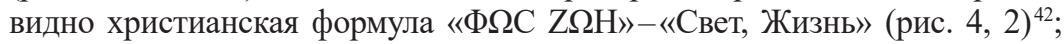
на втором-крестовидная монограмма, образованная греческими буквами $\Gamma, \mathrm{E}, \Omega, \mathrm{P}, \mathrm{A}$ (рис. $4,3,3 \mathrm{a})$, что позволяет прочитать женское христианское

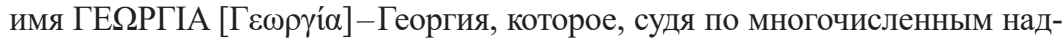
писям на мозаиках и надгробиях, происходящих из разных регионов Восточно-римской империи, было популярно в раннесредневековое время ${ }^{43}$. Перстень с монограммой имени считается показателем высокого социального статуса его носителя. В VII в. золотые перстни с такой монограммой, выгравированной на круглом плоском щитке, носили представители византийской знати и элиты союзных империи варваров ${ }^{44}$. Судя по парадному костюму, в состав которого входили массивные серебряные аксессуары

\footnotetext{
${ }^{42}$ См.: Хайрединова Э. А. Византийские перстни с надписью «Ф $\Omega \mathrm{C} Z \Omega H »$ из погребений крымских готов // Вестник Волгоградского государственного университета. Серия 4, История. Регионоведение. Международные отношения. 2018. Т. 23, № 5. С. 88-104.

${ }^{43}$ См.: Lefebvre G. Recueil des inscriptions grecques-chrétiennes de l'Égypte. Le Caire, 1907. P. 18-19. No 81; Asdracha C. Inscriptions protobyzantines et byzantines de la Thrace Orientale et de l'île d'Imbros (IIIe-XVe siècles). Athenes, 2003. P. 508.

${ }^{44}$ См.: Залесская В.Н. Памятники византийского прикладного искусства... С. 92. Art of Late Rome and Byzantium... P. 50-53.
} 


\section{Э.А. Хайрединова}

и золотые украшения, а также многочисленные металлические подвески и крупные бус из стекла и янтаря, молодая женщина по имени Георгия, похороненная во второй половине VII в. в одном из склепов могильника у с. Лучистое, также имела особый социальный статус.

В женском погребении конца VI-первой четверти VII вв. из склепа 154 из Лучистого перстень варианта $B$ лежал не на костях рук, а на ребрах, среди бус и подвесок, образовывавших нагрудные, так называемые «фибульные» ожерелья (рис. 5, II). В традиционном женском костюме крымских готов фибулы часто соединялись толстой нитью с 11-36 крупными бусинами из янтаря, одноцветного и полихромного стекла, а также из меловой породы и горного хрусталя. Концы нити привязывались к пружинам фибул. В «фибульных» ожерельях бусы располагались в определенном порядке: изделия из природных материалов чередовались со стеклянными. Вместе с бусами на нить, соединявшую фибулы, нередко нанизывались колокольчики, звон которых, как считалось, отгонял злых духов ${ }^{45}$. Фибульное ожерелье, в отличие от низки бус на шее, было своеобразным средоточием амулетов, так как каждый его элемент имел определенное оберегающее значение ${ }^{46}$. Присутствие в таком ожерелье перстня, наделенного защитными свойствами христианского символа, выглядит вполне естественно.

Бронзовый перстень варианта $B$ с крестом, совмещенным с христограммой, висевший в фибульном ожерелье похороненной в склепе 154 женщины (рис. 5, II, 2), мог использоваться как амулет для здоровья. В качестве примера такого назначения украшения с изображением креста можно привести происходящий из Сирии бронзовый перстень VIVII вв., на щитке которого вокруг креста выгравирована надпись ҮГIA СЕРГІОУ («Здоровье Сергию») ${ }^{47}$. Интересно, что в склепе 154 в слое, перекрывавшем названное женское погребение, обнаружен костяк другой женщины, похороненной в первой четверти VII в., на котором вместе с бусами и подвесками от фибульного ожерелья лежал бронзовый пер-

\footnotetext{
${ }^{45}$ См.: Кагаров Е.Г. Культ фетишей, растений и животных в Древней Греции. СПб, 1913. C. 83. Russell J. The Archaeological Context of Magic in the Early Byzantine Period// Byzantine Magic / Ed. H. Maguire. Washington, 1995. P. 42-43.

46 Понять значение некоторых бусин помогают данные этнографии. Так, например, на Северном Кавказе женщины хранили в специальной шкатулке 9-10 крупных старинных бусин, каждая из которых имела свое назначение: с волнистой полоской вдоль центра-«от змей», желтая с мелкими глазками-«от оспы», синяя глазчатая-«от сглаза» и т.д. См.: Иерусалимская А. А. Некоторые вопросы изучения раннесредневекового костюма (по материалам анализа одежды адыго-аланских племен VIII-IX вв.) // Культуры Евразийских степей второй половины I тысячалетия н.э. (из истории костюма). Самара, 2001. С. 95.

${ }^{47}$ Cм.: Die Kunst der frühen Christen in Syrien. Zeichen, Bilder und Symbole vom 4. bis 7. Jahrhundert / Eds. M. Fansa, B. Bollmann. Mainz, 2008. S. 152-153. Kat. No 38.
} 
Перстни с изображением креста второй половины VI-VII в.

стень с выгравированным на щитке Хнубисом-змеем с львиной головой в нимбе. Украшения с изображением этого существа относятся к группе медицинских магических амулетов, предназначавшихся для улучшения пищеварения и для лечения болезней пищеварительного тракта. Женщина, которой принадлежал перстень с Хнубисом, носила его в нагрудном ожерелье, на уровне желудка-именно так, как рекомендовалось в медицинских трактатах носить амулеты против болей в животе ${ }^{48}$.

Изображение креста не использовалось для декорирования предметов. Крест, прежде всего-религиозный символ, знак принадлежности христианской конфессии. Видимо и перстни с изображением креста не были простым украшением, а в представлении носивших их людей приравнивались к предмету личного благочестия, служили своего рода аналогом нательному кресту. Кроме того, в самой символике креста заложена защитно-охранительная функция, и его изображение на щитке перстня должно было придать оберегающие свойства изделию.

Присутствие изображения креста именно на перстнях неудивительно. Известно, что в эпоху раннего Средневековья на перстнях часто помещались надписи защитного характера и определенные изображения, наделявшие украшение лечебной силой ${ }^{49}$. Александр из Тралл (525-605) знаменитый медик, которого Агафий Миринейский назвал «опытнейшим во врачебном искусстве» ${ }^{50}$, рекомендовал делать амулеты против желчи из металлического перстня путем нанесения на нем слов «беги, беги, о желчь: жаворонок тебя ищет» ${ }^{51}$. Он же советовал в качестве оберега против почечных камней носить золотое кольцо с щитком из кипрской меди с изображением льва, луны и звезды ${ }^{52}$. Скорее всего, к такого рода медицинским амулетам относились бронзовые перстни конца VI-первой половины VII вв., найденные на территории Израиля, с круглым или овальным щитком с выгравированным рычащем львом с поднятым хвостом, идущим вправо ${ }^{53}$. Терапевтические

${ }_{48}$ См.: Хайрединова Э.А. Перстень-амулет первой четверти VII в. Из Юго-Западного Крыма // АДСВ. 2014. Вып. 42. С. 74-82, 89. Рис. 6.

${ }^{49}$ См.: Baldini-Lippolis I. L'oreficeria nell' Imperio... P. 187-188.

${ }^{50}$ См.: Агафий. О царствовании Юстиниана / Пер., ст. и прим. М.В. Левченко. М.; Л., 1953. C. 143. V,6.

${ }^{51}$ CM.: Schlumberger $G$. Amulettes Byzantins anciens destinées à combattre les maléfices et les maladies // Revue des Études grecques. 1892. T. 5. Fasc. 17. P. 87.

${ }^{52}$ CM.: Brunet F. Oeuvres médicales d'Alexandre de Tralles, tome IV. Paris, 1937. P. 170. XI.1; Sodini J.-P. La terre des semelles... P. 134.

${ }^{53}$ Cм.: Baldini-Lippolis I. L'oreficeria nell' Imperio... P. 205, No7-9; Amorai-Stark Sh., Hershkovitz M. Selected Antique Gems from Israel Excavated Glyptics from Roman-Byzantine Tombs // «Gems of Heaven». Recent Research on Engraved Gemstones in Late Antiquity, c. AD200-600 / Eds. Ch. Entwistle, N. Adams. British Museum research Publication. London, 2012. No 177. P. 107. Pl. 16. 


\section{Э.А. Хайрединова}

свойства приписывались и серебряным перстням без изображений. Так, в «Геопониках», византийской сельскохозяйственной энциклопедии X в., сообщается, что укус скорпиона можно вылечить, припечатав это место серебряным перстнем ${ }^{54}$.

Подводя итоги, можно отметить следующее. Во второй половине VI-VII вв. в Юго-Западном Крыму пользовались популярностью привозившиеся из Византии и производившиеся в местных мастерских по импортным образцам перстни с изображением креста. Они найдены в погребениях мужчин-воинов и молодых женщин, имевших высокий социальный статус. Большинство перстней происходит из женских захоронений. Женщины носили их на руках, как правило, на правом указательном пальце и в нагрудных ожерельях, соединявших фибулы. Крест, размещенный на щитке перстня, в представлении древних христиан должен был наделить украшение свойствами амулета, оберегавшего носившего его человека от всяких бед.

Изучение перстней позволяет не только расширить знания об украшениях, бытовавших в раннесредневековое время, но и пополняет наши сведения о повседневной жизни и верованиях жителей раннесредневекового Крыма. Находки подобного рода свидетельствуют о единстве культуры в христианском мире и являются наглядным примером тесных экономических и культурных связях Крыма с Византийской империей в эпоху раннего Средневековья.

$\begin{array}{ll}\text { Хайрединова Эльзара Айдеровна } & \text { Khairedinova, Elzara Aiderovna } \\ \text { кандидат исторических наук, за- } & \mathrm{PhD} \text { (History), Head of the Mediaeval } \\ \text { ведующая отделом средневековой } & \text { Archeology Department } \\ \text { археологии } & \text { Institute of Archaeology of Crimea of the } \\ \text { Институт археологии Крыма РАН } & \text { Russian Academy of Sciences } \\ \text { 295007Симферополь, пр. Вернад- } & \text { 2, Vernadskogo Ave, 295007 Simferopol, Russia } \\ \text { ского, 2 } & \text { E-mail: khairedinovaz@rambler.ru } \\ \text { E-mail: khairedinovaz@rambler.ru } & \text { ORCID: 0000-0002-1362-757X }\end{array}$

Elzara A. Khairedinova

Institute of Archaeology of Crimea of the Russian Academy of Sciences, Simferopol, Russia

\section{FINGER RINGS WITH THE IMAGE OF THE CROSS FROM THE SECOND HALF OF SIXTH AND SEVENTH CENTURIES FROM THE SOUTH-WESTERN CRIMEA}

\footnotetext{
${ }^{54}$ См.: Геопоники. Византийская сельскохозяйственная энциклопедия Х века / Введ., пер. с греч. и комм. Е.Э. Липшиц. М.; Л., 1960. ХІІІ, 9.2.
} 
Перстни с изображением креста второй половины VI-VII в.

Abstract: In the second half of $6^{\text {th }}-7^{\text {th }}$ centuries in the South-Western Crimea, finger rings imported from Byzantium and produced in the local workshops on imported patterns with a cross were popular with Goth-Alanian population. According to the peculiarities of the image, they are presented in four variants: A-with a deeply cut equal-ended cross with flared tips; $\mathrm{B}-$ with a cross formed by engraved geometric figures; $\mathrm{B}$-with a cross formed by thin mortise lines with cross lines at the ends; $\Gamma$-with a cross-shaped flap with flared ends, the surface of which is inlaid with glass. The finger rings with the cross originating from the Crimea belonged to male warriors and young women who had a high social status. Most of the finger rings come from female burials. Women wore them on their hands, as a rule, on the right index finger and in the breast necklaces that connected fibulas. The image of the cross was not used for decorating objects. The cross, first of all, is a religious symbol, a sign of belonging to a Christian denomination. Apparently, the finger rings with the image of the cross were not a simple piece of jewellery, but in the view of the people wearing them, they were equated with the subject of personal piety, served as a kind of analogue to the cross under clothes. In addition, the cross in its very symbolism performed a protective function. The image of the cross on the shield of the ring endowed the item of jewellery with the properties of an amulet that protected the person who wore it from all misfortunes. The study of finger rings allows us not only to expand knowledge about the items of jewellery that existed in the early medieval time, but also adds to our knowledge of everyday life and the beliefs of the inhabitants of the early medieval Crimea. Findings of this kind testify to the unity of culture in the Christian world and are a good example of the close economic and cultural ties of Crimea with the Byzantine Empire in the early Middle Ages.

Keywords: Byzantium, South-Western Crimea, Crimean Goths, Byzantine jewellery, finger rings, cross

Submitted: 22.06 .2019

Accepted: 11.11.2019

\section{References}

Ajbabin, A. I. “Khronologiia mogil'nikov Kryma pozdnerimskogo i rannesrednevekovogo vremeni." Materialy po arheologii, istorii i etnografi Tavrii 1 (1990). P. 3-86. 1999.

Aibabin, A.I. Etnicheskaia istoriia rannevizantiiskogo Kryma. Simferopol,

Aibabin, A. I. "Arkheologicheskoe nasledie khazar vremeni sozdaniia kagana-

ta." Materialy po akrheologii, istorii i etnografii Tavrii 18 (2013). P. 277-315.

Aibabin, A. I., Khairedinova, E.A. Mogil'nik u sela Luchistoe. T. I (Raskopki 1977, 1982-1984 gg.). Simferopol; Kerch, 2008.

Aibabin, A. I., Khairedinova, E.A. Mogil'nik u sela Luchistoe. T. II (Raskopki 1984, 1986, 1991, 1993-1995 godov). Simferopol; Kerch, 2014.

Aibabin, A. I., Khairedinova, E.A. Krymskie goty strany Dori (seredina IIIVII vv.). Simferopol, 2017. 


\section{Э.А. Хайрединова}

Ajbabin, A. I., Hajredinova, E. A. "Ein neuer gotischer Fundkomplex aus dem Gräberfeld beim Dorf Lučistoe." In Studia Barbarica: Profesorowi Andrzejowi Kokowskiemu w 65. rocznice urodzin. T. I. Lublin, 2018. S. 396-407.

Amorai-Stark, Sh., Hershkovitz, M. "Selected Antique Gems from Israel Excavated Glyptics from Roman-Byzantine Tombs." In Entwistle, Ch., and Adams, N., eds. "Gems of Heaven». Recent Research on Engraved Gemstones in Late Antiquity, c. AD200-600. (British Museum research Publication, 177). London, 2012. P. 105-113.

Arrhenius, B. "Garnet Jewelry of the Fifth and Sixth Centuries." In Brown, K. R., Kidd, D., and Little, Ch. T., eds. From Attila to Charlemagne. Arts of the Early medieval Period in The metropolitan Museum of Art. New York, 2000. P. 214-225.

Asdracha, C. Inscriptions protobyzantines et byzantines de la Thrace Orientale et de l'île d'Imbros (IIIe-XVe siècles). Athenes, 2003.

Baldini-Lippolis, I. L'oreficeria nell' Imperio di Constantinopoli tra IV e VII secolo. Bari, 1999.

Bénazeth, D. L'art du métal au début de l'ère chrétienne. Paris, 1992.

Brunet, F. Oeuvres médicales d'Alexandre de Tralles. T.4. Paris, 1937.

Droberjar, E. “'A propos des contacts entre l'empire d'Orient et les Germains de l'Elbe au VIe siècle." In Ivanišević, V., and Kazanski, M., eds. The Pontic-Danubian Realm in the Period of the Great Migration. Paris; Beograd, 2012. P. 297-316.

Garam, E. Funde byzantinischer Herkunft in der Awarenzeit vom Ende des 6. bis zum Ende des 7. Jahrhunderts. Budapest, 2001.

Gonosová, A., Kondoleon, Ch., eds. Art of Late Rome and Byzantium in the Virginia Museum of Fine Arts. Richmond, 1994.

Fansa, M., Bollmann, B., eds. Die Kunst der frühen Christen in Syrien. Zeichen, Bilder und Symbole vom 4. bis 7. Jahrhundert. Mainz, 2008.

Henner, J., Förster, H., Horak, U., eds. Christliches mit Feder und Faden. Christliches in Texten, Textilien und Alltagsgegenständen aus Ägypten. Wien, 1999.

Hörandner, W., Carr, A. W. "Christogram." In Kazhdan, A. P., ed. The Oxford Dictionary of Byzantium. Vol. 1. New York; Oxford, 1991. P. 441.

Ierusalimskaja, A. A. "Nekotorye voprosy izucheniia rannesrednevekovogo kostiuma (po materialam analiza odezhdy adygo-alanskikh plemen VIII-IX vv.)." In Kul'tury Evraziiskikh stepei vtoroi poloviny I tysiacheletiia n.e. (iz istorii kostiuma). Samara, 2001. P. 87-105.

Kagarov, E. G. Kul't fetishei, rastenii i zhivotnykh v Drevnei Grecii. St Petersburg, 1913.

Khairedinova, E. A. "Raskopki nekropolia na sklone plato Eski-Kermen v 2006-2008 gg." Materialy po arkheologii, istorii i etnografii Tavrii 16 (2010). P. 140-213.

Khairedinova, E. A. "Perstni i kol'ca rannesrednevekovogo vremeni iz Kerchi." Bosporskie issledovaniia 30 (2014). P. 442-460.

Khairedinova, E. A. "Persten'-amulet pervoi chetverti VII v. iz Iugo-Zapadnogo Kryma." Antichnaya drevnost'i srednie veka 42 (2014). P. 69-89.

Khairedinova, E. A. "Vizantiiskie kresty s inkrustatsiei iz Iugo-Zapadnogo Kryma." Vestnik Volgogradskogo gosudarstvennogo universiteta. Seriya 4. Istoriya. Regionovedenie. Mezhdunarodnye otnosheniya 22,5 (2017). P. 86-99. 
Перстни с изображением креста второй половины VI-VII в.

Khairedinova, E. A. "Geral'dicheskii poiasnoi nabor s khristianskoi simvolikoi vtoroi poloviny VI v. iz mogil'nika u s. Luchistoe." Materialy po arkheologii, istorii i etnografii Tavrii 23 (2018). P. 207-232.

Khairedinova, E. A. "Vizantiiskie perstni s nadpis'iu « $\Phi \Omega S \mathrm{Z} \Omega H »$ iz pogrebenii krymskih gotov." Vestnik Volgogradskogo gosudarstvennogo universiteta. Seriya 4. Istoriya. Regionovedenie. Mezhdunarodnye otnosheniya 23,5 (2018). P. 88-104.

Kazanski, M. Qal'at Sem'an. Vol. IV: Rapport final. Fascicule 3: Les objets métalliques. Beyrout, 2003.

Lefebvre, G. Recueil des inscriptions grecques-chrétiennes de l'Égypte. Le Caire, 1907.

Levchenko, M.V., ed. Agafii. O tsarstvovanii Iustiniana. Moscow; Leningrad, 1953.

Lipshic, E. E., ed. Geoponiki. Vizantiiskaia sel'skokhoziaistvennaia entsiklopediia X veka. Moscow; Leningrad, 1960.

Papanikola-Bakirtzi, D., ed. Everyday Life in Byzantium. Athens, 2002.

Pallas, D. "Données nouvelles sur quelques boucles et fibules considérées comme avares et slaves sur Corinthe entre le VIe et le IXe s." Byzantinobulgarica 7 (1981). P. 295-318.

Pirson, A. "Byzantinischer Schmuck und Trachtbestanteile aus Pergamon." Byzas 15 (2012). S. 173-186.

Poulou-Papadimitriou, N. "Les plaques-boucles byzantines de l'île de Crète (fin IVe-IXe siècle)." Travaux et Mémoires 15 (2005). P. 687-704.

Otten, T., Evans, J., Lamb, A., Müldner, G., Pirson, A., Teegen, W.-R. "Ein frühbyzantinisches Waffengrab aus Pergamon. Interpretationsmöglichkeiten aus archäologischer und naturwissenschaftlicher Sicht." Istanbuler Mitteilungen 61 (2011). S. 347-432.

Riemer, E. Romanische Grabfunde des 5.-8. Jahrhunderts in Italien [Internationale Archäologie, 57]. Rahden/Westfalien, 2000.

Russell, J. "The Archaeological Context of Magic in the Early Byzantine Period.” In Maguire, H., ed. Byzantine Magic. Washington, 1995. P. 35-50.

Schlumberger, G. "Amulettes Byzantins anciens destinées à combattre les maléfices et les maladies." Revue des Études grecques 5/17 (1892). P. 73-93.

Schulze-Dörrlamm, M. Byzantinische Gürtelschnallen und Gürtelbeschläge im Römisch-Germanischen Zentralmuzeum. Teil II: Die Schnallen mit Scharnierbeschläg und die Schnallen mit angegossenem Riemendurchzug des 7. bis 10. Jahrhunderts. Mainz, 2009.

Sodini, J.-P. "La terre des semelles: images pieuses ramenées par les pèlerins des Lieux saints (Terre sainte, Martyria d'Orient)." Journal des savants 1 (2011). P. 77-140.

Spier, J. Late Antique and Early Christian Gems. Wiesbaden, 2007.

Spieser, J.-M. "Collection Paul Canellopoulos (II). Bagues romaines et médiévales." Bulletin de correspondence hellénique 96,1 (1972). P. 117-135.

Sulzberger, M. "Le symbole de la croix et les monogrammes de Jésus chez les premiers Chrétien." Byzantion 2 (1925). P. 393-397. 1992.

Uense, S. Die spätantiken Befestigungen von Sadovec (Bulgarien). München, 


\section{Э.А. Хайрединова}

Vejmarn, E. V., Aibabin, A. I. Skalistinskii mogil'nik. Kiev, 1993.

Vikan, G. "Early Christian and Byzantine Rings in the Zucker Family Collection." The Journal of the Walters Art Gallery 45 (1987). P. 32-43.

Waldbaum, J.C. Metalwork from Sardis. London; Cambridge, 1983.

Wamser, L., ed. Die Welt von Byzanz. Europas Östliches Erbe. München, 2004.

Weitzmann, K., ed. Age of Spirituality: Late Antique and Early Christian Art, Third to Seventh Century: Catalogue of the Exhibition. New York, 1979.

Zalesskaja, V.N. Pamiatniki vizantiiskogo prikladnogo iskusstva IV-VII vv.: katalog kollektsi. St Petersburg, 2006.

\section{ИЛЛЮСТРАЦИИ}

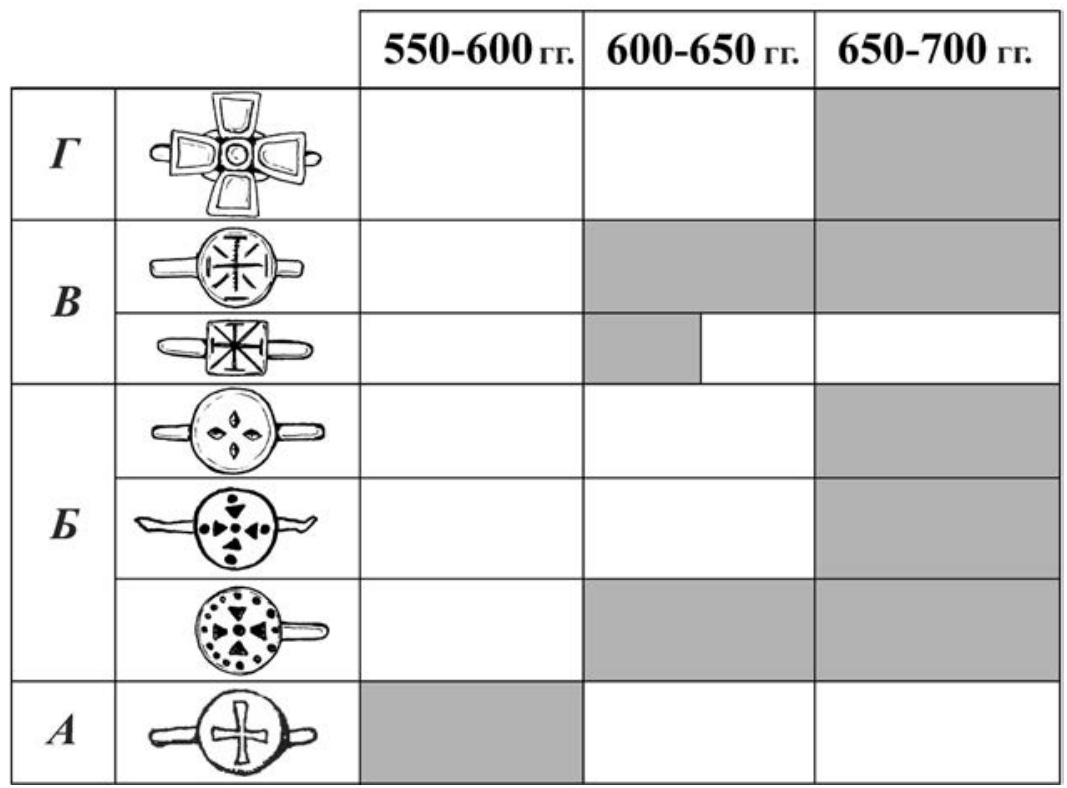

Рис. 1. Типология и хронология раннесредневековых перстней с изображением креста из Юго-Западного Крыма

Fig. 1. Typology and chronology of early medieval finger rings depicting a cross from the South-Western Crimea 
Перстни с изображением креста второй половины VI-VII в.

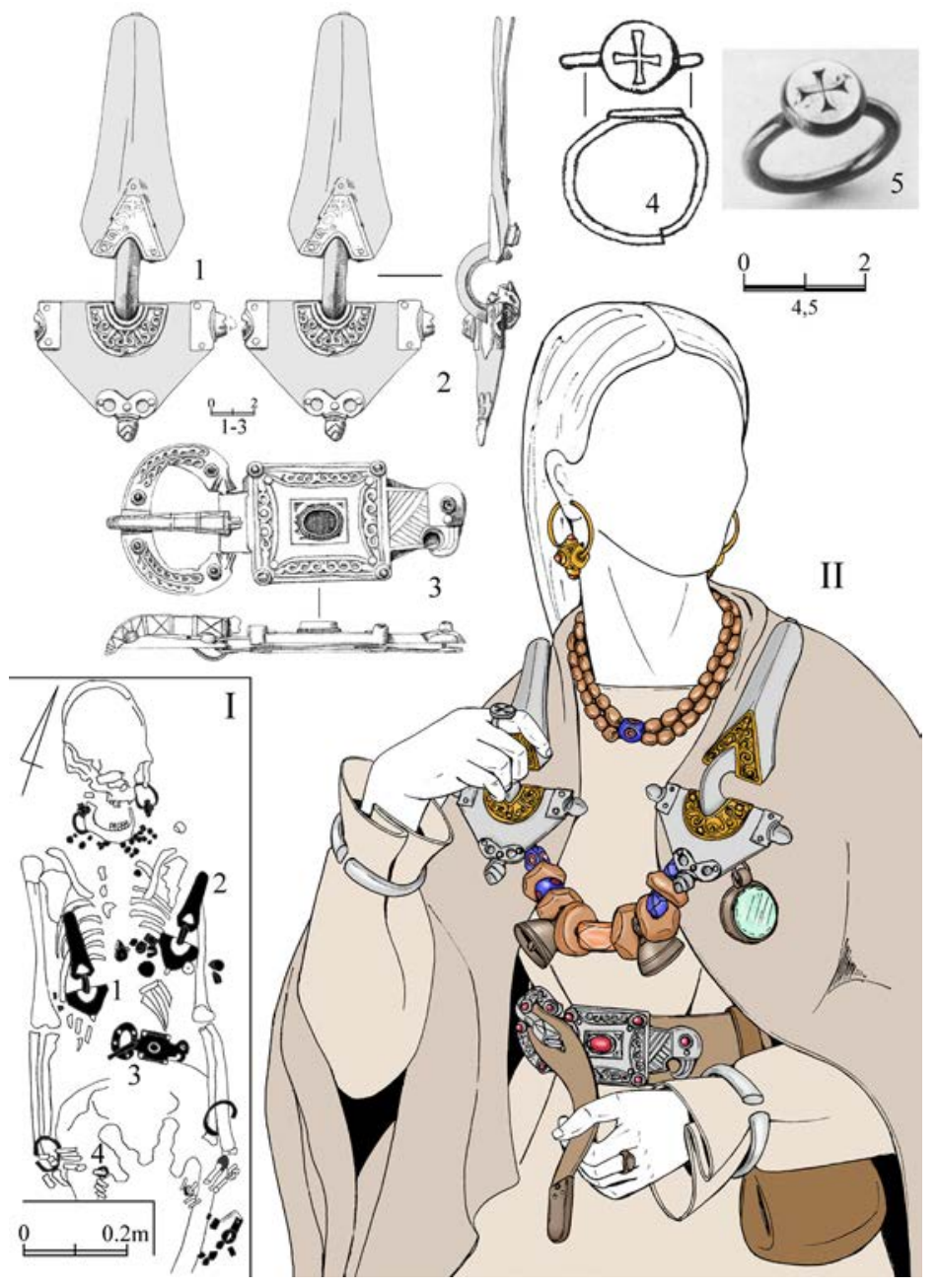

Рис. 2. Женское погребение второй половины VI в. из склепа 2 могильника Alonia (Юго-Западный Крым) (I; II; 1-4) и византийский золотой перстень с выгравированным крестом из собрания Музея украшений в Пфорцхайме (5).

Реконструкция и рисунок автора

Fig. 2. Female burial of the second half of the 6th century from the crypt 2 of the Alonia cemetery (South-Western Crimea) (I; II; 1-4) and a Byzantine gold ring with an engraved cross from the collection of the Museum of Jewellery in Pforzheim (5). Reconstruction and drawing of the author 
Э.А. Хайрединова

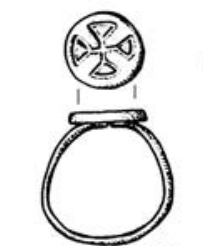

12
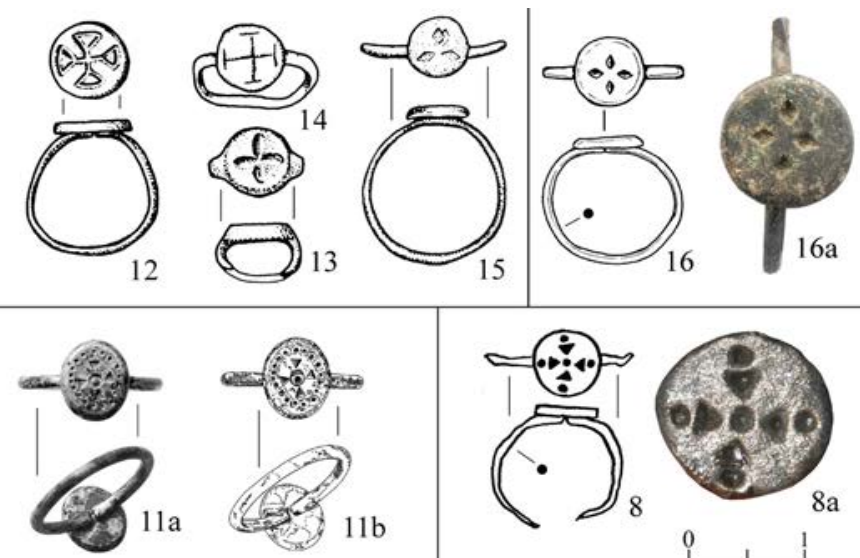

$11 \mathrm{~b}$
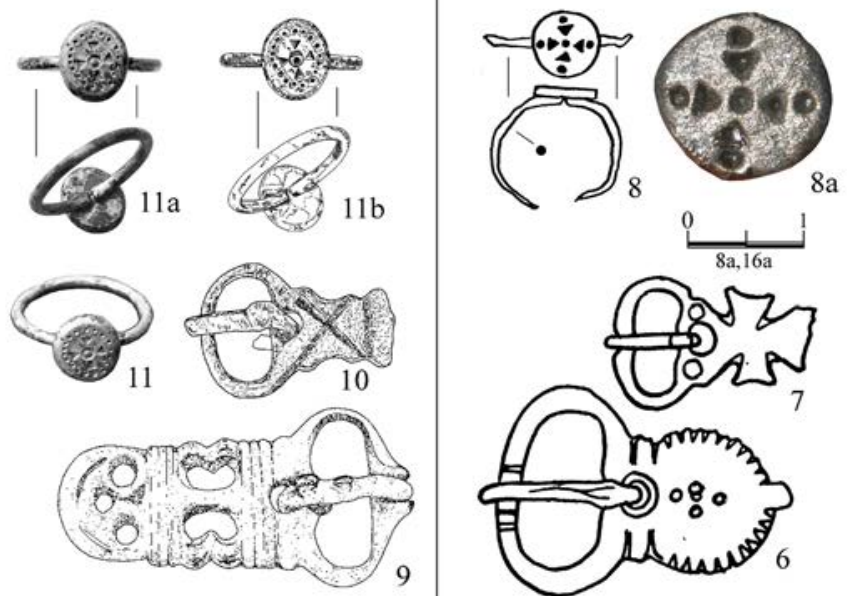

9
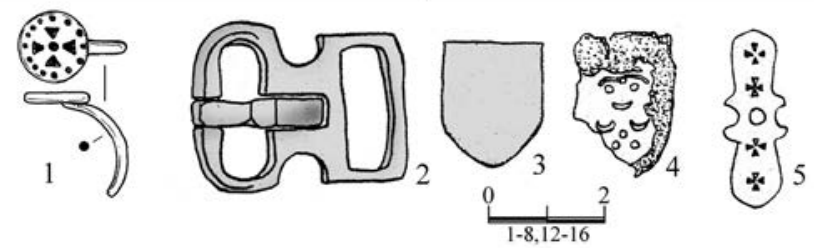

Рис. 3. Византийские серебряные перстни варианта $E$ с крестом, образованным гравированными геометрическими фигурами, второй половины VII в. из ЮгоЗападного Крыма $(1,8,16)$ и их аналогии из Малой Азии (11) и Подунавья $(12-15)$ : 1-5 - Скалистое, склеп 325; 6-8 - Эски-Кермен, склеп 193; 9-11 - Пергам; 16 Лучистое, склеп 228; 12-15 - Венгрия, аварские могильники (12 - Bóly; 13 - Cikó;

14 - Vajska; 15 - Vác-Kavicsbánya)

Fig. 3. Byzantine silver finger rings of variant $B$ with a cross formed by engraved geometric figures, second half of the $7^{\text {th }}$ century from the South-Western Crimea $(1,8,16)$

and their analogies from Asia Minor (11) and the Danube (12-15): 1-5 - Skalistoye, crypt 325; 6-8 - Eski-Kerman, crypt 193; 9-11 - Pergamon; 16 - Luchistoye, crypt 228; $12-15$ - Hungary, Avar burial grounds 
Перстни с изображением креста второй половины VI-VII в.

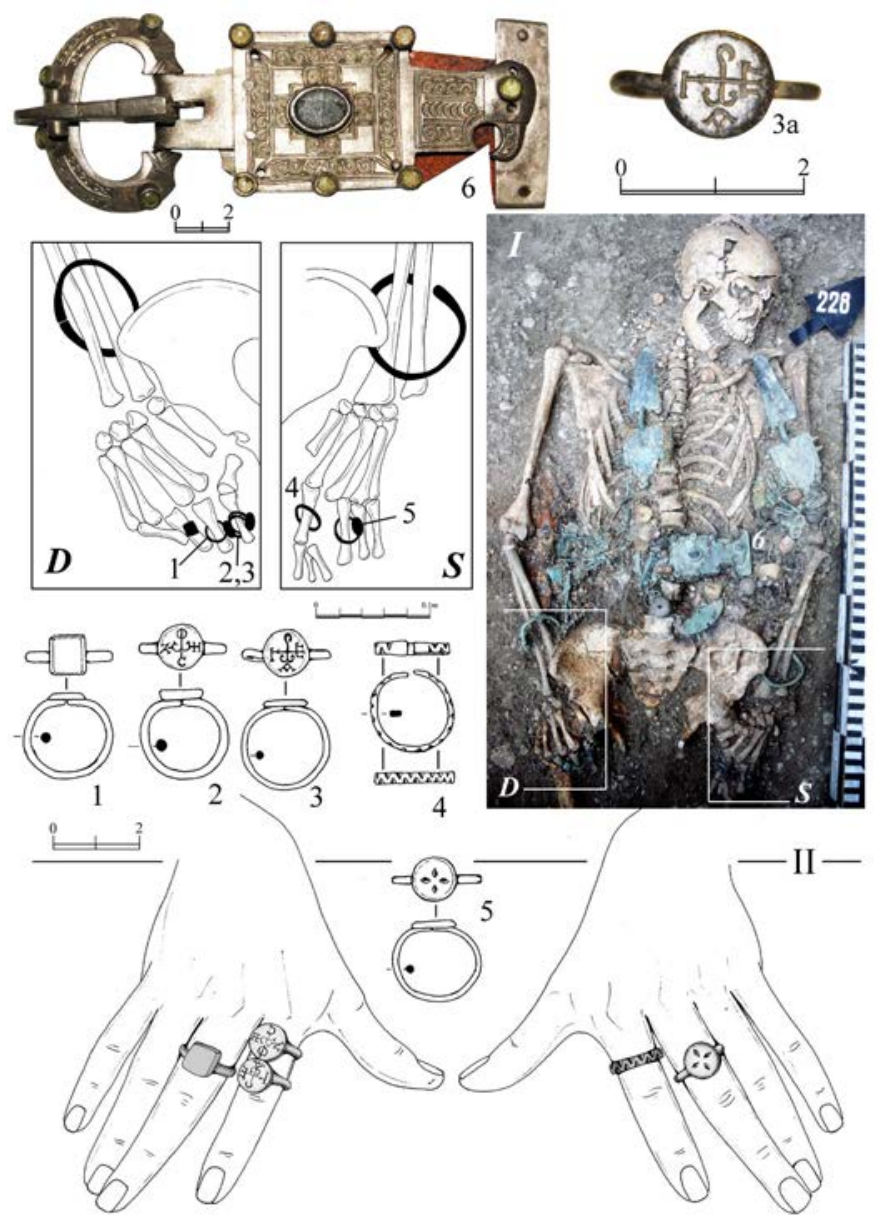

Рис. 4. Женское погребение второй половины VII в. из склепа 228 могильника у с. Лучистое (Юго-Западный Крым): I - план погребения; II - реконструкция рук погребенной с перстнями; D - зафиксированное in situ расположение перстней на костях правой руки; S - зафиксированное in situ расположение перстня и кольца на костях левой руки; 1-6 - находки из погребения. Реконструкция, фото и рисунок автора

Fig. 4. Female burial of the second half of $7^{\text {th }}$ century from the crypt of the 228 burial ground at the village of Luchistoye (South-Western Crimea): I - burial plan; II - reconstruction of the hands of the buried woman with finger rings; D - fixed in situ position of rings on the bones of the right hand; $\mathrm{S}$ - fixed in situ position of the ring and ring on the bones of the left hand; $1-6$ - findings from the burial. Reconstruction, photo and drawing of the author 


\section{Э.А. Хайрединова}
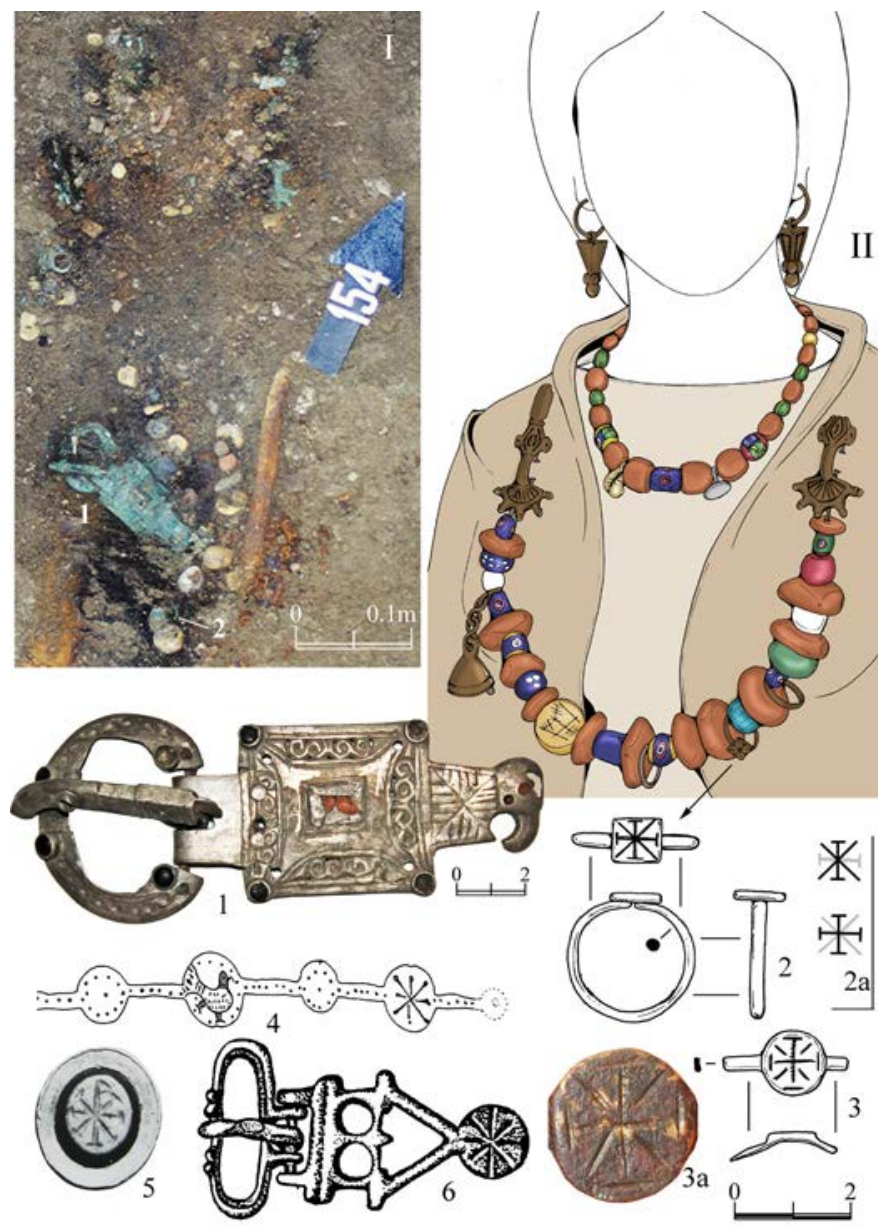

Рис. 5. Женское погребение конца VI - первой четверти VII вв. из склепа 154 могильника у с. Лучистое (Юго-Западный Крым) (I, II, 1, 2) и византийские изделия с изображением креста, совмещенного с христограммой (3-6): 3 - ЭскиКермен; 4 - Египет; 5 - Восточное Средиземноморье; 6 - Скалистое, склеп 307а.

Реконструкция, фото и рисунок автора

Fig. 5. Female burial of the end of the $6^{\text {th }}-$ the first quarter of the $7^{\text {th }}$ century from the crypt of 154 burial grounds at the village of Luchistoye (South-Western Crimea) (I, II, $1,2)$ and Byzantine products with the image of the cross, combined with the Christgram (3-6): 3 - Eski-Kerman; 4 - Egypt; 5 - Eastern Mediterranean; 6 - Skalistoye, crypt 307a. Reconstruction, photo and drawing of the author 
Перстни с изображением креста второй половины VI-VII в.

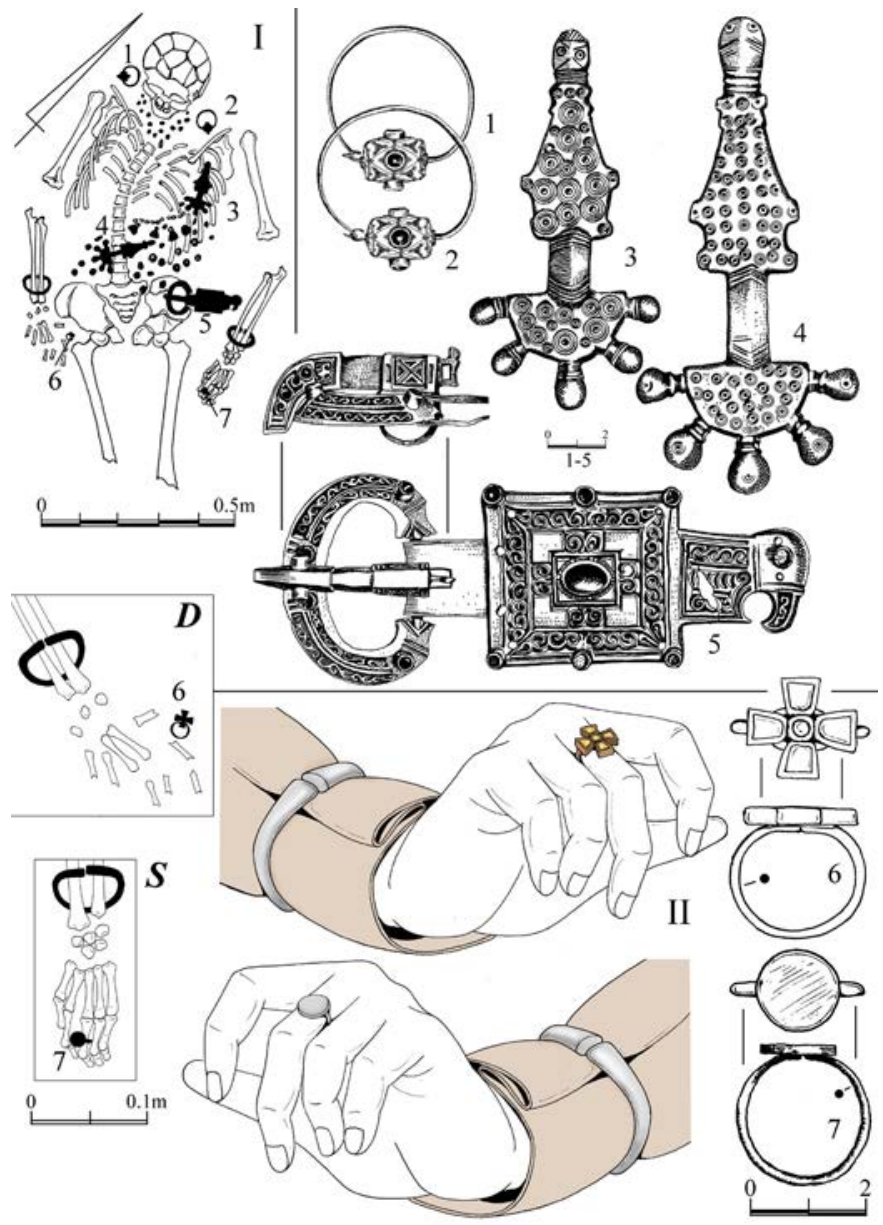

Рис. 6. Женское погребение второй половины VII в. из склепа 43 могильника у с. Лучистое (Юго-Западный Крым): I - план погребения; II - реконструкция рук погребенной с перстнями; D - зафиксированное in situ расположение перстня на костях правой руки; $\mathrm{S}$ - зафиксированное in situ расположение перстня на костях левой руки; 1-7 - находки из погребения. Реконструкция и рисунок автора

Fig. 6. Female burial of the second half of the $7^{\text {th }}$ century from the crypt 43 of the cemetery at the village of Luchistoye (South-Western Crimea): I - burial plan; II reconstruction of the hands of the buried woman with finger rings; D - fixed in situ ring position on the bones of the right hand; $\mathrm{S}$ - fixed in situ ring position on the bones of the left hand; 1-7 - findings from the burial. Reconstruction and drawing of the author 